\title{
PENJERAPAN GAS CO HASIL PEMBAKARAN SAMPAH MENGGUNAKAN SORBENT TERMODIFIKASI DALAM REAKTOR FIXED BED
}

\author{
Mariana $^{\left.1^{*}\right)}$, Farid Mulana ${ }^{1)}$, dan Purwana Satriyo ${ }^{2)}$ \\ 1) Jurusan Teknik Kimia, Fakultas Teknik, Universitas Syiah Kuala, Banda Aceh \\ Jl. Tgk. Syeh Abdul Rauf No. 7, Darussalam, BandaAceh, 23111 \\ 2) Jurusan Teknik Pertanian, Fakultas Pertanian, Universitas Syiah Kuala, Banda Aceh \\ Jl. Tgk. Hasan Krueng Kalee No. 10, Darussalam, Banda Aceh, 23111 \\ ${ }^{*}$ Penulis korespondensi : mariana_hasyim@yahoo.com
}

\begin{abstract}
ADSORPTION OF CO FROM WASTE COMBUSTION USING MODIFIED SORBENT IN A FIXED BED REACTOR. Gases produced by garbage burning consist of dangerous gases such as $\mathrm{CO}, \mathrm{SO}_{2}$ and other gases. Technology for reducing dangerous gases from incinerator outlet can be done by using a dry or wet process. The dry process is more economical process because of simple process, easy maintenance and no liquid waste as product. However, the weakness of the dry process is low absorption conversion and low gas removal efficiency. One way to overcome these problems is to use sorbent which has high reactivity. An inexpensive sorbent that commonly used is $\mathrm{Ca}(\mathrm{OH})_{2}$. The aim of this research was to increase the reactivity of $\mathrm{Ca}(\mathrm{OH})_{2}$ sorbent by using diatomaceous earth and compost as a source of silica and biosorbent, respectively. Diatomaceous earth contains $\mathrm{CaO}$, $\mathrm{SiO}_{2}$ and $\mathrm{Al}_{2} \mathrm{O}_{3}$ and compost contains bacteria as a biosorbent that can convert $\mathrm{CO}$ to $\mathrm{CO}_{2}$ and $\mathrm{CH}_{4}$. The reaction between $\mathrm{SiO}_{2}$ and $\mathrm{Ca}(\mathrm{OH})_{2}$ would form calcium silicate hydrate $\left(\mathrm{CaO} \cdot \mathrm{SiO}_{2} \cdot 2 \mathrm{H}_{2} \mathrm{O}\right)$ that has a high porosity and reactivity. The results showed that the reactivity of $\mathrm{Ca}(\mathrm{OH})_{2}$ sorbent increased by addition of diatomaceous earth and compost. The results also showed that the sorption of $\mathrm{CO}$ gas increases with increasing of height of sorbent bed and temperature. The highest $\mathrm{CO}$ gas sorption was obtained at temperature of $150^{\circ} \mathrm{C}$ and sorbent bed height of $6 \mathrm{~cm}$ using the modified sorbent with $\mathrm{Ca}(\mathrm{OH})_{2} / \mathrm{DE} /$ compost ratio of 3:1:1.
\end{abstract}

Keywords: fixed bed reactor; gas sorption; sorbent $\mathrm{Ca}(\mathrm{OH})_{2} /$ Diatomaceous earth/compos

\begin{abstract}
Abstrak
Gas hasil pembakaran sampah terdiri dari gas-gas yang berbahaya seperti $\mathrm{CO}, \mathrm{SO}_{2}$ dan lain sebagainya. Teknologi penghilangan gas-gas tersebut dapat dilakukan dengan menggunakan proses kering maupun proses basah. Penghilangan dengan proses kering lebih ekonomis karena sederhana, mudah pemeliharaan dan tidak menghasilkan limbah cair. Namun demikian, kelemahan proses kering adalah konversi absorpsi rendah dan efisiensi penyisihan gas relatif kecil. Salah satu cara mengatasi masalah tersebut di atas adalah dengan menggunakan sorbent yang mempunyai reaktifitas yang tinggi. Sorbent yang umum digunakan dan murah adalah $\mathrm{Ca}(\mathrm{OH})_{2}$. Penelitian ini bertujuan untuk meningkatkan reaktifitas sorbent $\mathrm{Ca}(\mathrm{OH})_{2}$ dengan menggunakan tanah diatomeae sebagai sumber silika dan kompos sebagai sumber biosorbent. Tanah diatomea umumnya mengandung $\mathrm{CaO}, \mathrm{SiO}_{2}$ dan $\mathrm{Al}_{2} \mathrm{O}_{3}$. Reaksi antara $\mathrm{SiO}_{2}$ dengan $\mathrm{Ca}(\mathrm{OH})_{2}$ membentuk kalsium silicate hidrat $\left(\mathrm{CaO} \cdot \mathrm{SiO}_{2} \cdot 2 \mathrm{H}_{2} \mathrm{O}\right)$ yang mempunyai porositas dan reaktifitas yang tinggi. Kompos mengandung bakteri sebagai biosorbent yang dapat mengubah gas $\mathrm{CO}$ menjadi $\mathrm{CO}_{2}$ dan $\mathrm{CH}_{4}$. Hasil penelitian menunjukkan bahwa reaktifitas sorbent $\mathrm{Ca}(\mathrm{OH})_{2}$ meningkat dengan penambahan $\mathrm{DE}$ dan kompos. Hasil penelitian juga menunjukkan bahwa penjerapan gas CO meningkat dengan meningkatnya tinggi unggun sorbent dan temperatur. Penjerapan gas CO tertinggi diperoleh pada penggunaan modifikasi sorbent $\mathrm{Ca}(\mathrm{OH})_{2} / \mathrm{DE} /$ kompos (3:1:1), temperatur $150^{\circ} \mathrm{C}$ dan tinggi unggun sorbent $6 \mathrm{~cm}$ dari variabel yang dilakukan.
\end{abstract}

Kata kunci: fixed bed reaktor; penjerapan gas; sorbent $\mathrm{Ca}(\mathrm{OH})_{2} /$ tanah diatome/kompos 


\section{PENDAHULUAN}

Jutaan sampah dibuang ke lingkungan setiap harinya. Sebagian besar sampah ditumpuk dalam bentuk landfill di permukaan tanah, dibuang ke sungai atau laut tanpa penanganan terlebih dahulu. Sampah merupakan masalah yang paling serius terutama untuk daerah perkotaan yang berpenduduk pesat. Salah satu penanganan sampah dapat dilakukan melalui proses pembakaran di dalam sebuah incinerator (alat pembakaran sampah).

Gas-gas hasil pembakaran sampah dalam incinerator unumnya mengandung: (1) debu; (2) gasgas seperti sulfur dioksida $\left(\mathrm{SO}_{2}\right)$, nitrogen oksida $\left(\mathrm{NO}_{\mathrm{x}}\right)$, carbon monoksida (CO), asam hydroklorik; (3) dan logam-logam. Semua gas-gas tersebut di atas sangat berbahaya karena dapat berekasi dengan radikal bebas di udara membentuk asam yang dapat menyebabkan terjadinya hujan asam dan penipisan lapisan ozone. Hal tersebut dapat menyebabkan terjadinya panas global bumi serta dapat menyebabkan berbagai penyakit seperti iritasi pernapasan, batuk dan sebagainya yang dapat meningkatkan angka kematian.

Berbagai teknologi proses penyisihan gas hasil pembakaran telah dilakukan (Iizuka dkk., 2013; Kanai dkk., 2012; Fujioka dkk., 2012; Castilho dkk., 2013). Proses yang umum digunakan adalah proses kering dan proses basah. Penggunaan proses kering mempunyai beberapa keunggulan dari proses basah antara lain: (1) murah; (2) mudah penanganan; dan (3) tidak menghasilkan limbah cair. Salah satu proses pemisahan gas secara kering yang efektif, sederhana, mudah penanganan dan murah adalah menggunakan reaktor fixed bed dengan menggunakan absorbent $\mathrm{Ca}(\mathrm{OH})_{2}$. Namun demikian proses ini juga mempunyai beberapa kelemahan antara lain adalah rendahnya konversi sorbent dan effisiensi pemisahan gas (Mariana dkk., 2003; Seno dkk., 1996; Uchida dkk., 1979).

Untuk meningkatkan efisiensi pemisahan gas dan meningkatkan reaktifitas sorbent (konversi kalsium), berbagai variasi bahan tambahan (additive) dapat ditambahkan kedalam sorbent. Sorbent yang diperoleh dengan mencampur kalsium $\left(\mathrm{Ca}(\mathrm{OH})_{2}\right)$ di dalam air dengan bahan mengandung silika dapat meningkatkan konversi kalsium dibandingkan dengan konversi kalsium yang diperoleh tanpa campuran additive (Garea dkk., 1996). Penambahan kompos ke dalam sorbent $\mathrm{Ca}(\mathrm{OH})_{2}$ bisa meningkatkan pemisahan gas CO yang disebabkan oleh bakteri sebagai biosorbent akan mengubah gas $\mathrm{CO}$ menjadi gas $\mathrm{CO}_{2}$ dan $\mathrm{CH}_{4}$ (Suprapto, 2003).

Berbagai literatur mengemukakan bahwa reaksi pozzolanic antara silika dengan $\mathrm{Ca}(\mathrm{OH})_{2}$ di dalam larutan (slurry) membentuk kalsium silikat hidrat (hydrated calcium silicates (CSHs)) dan kalsium alumina (CAHs) yang tinggi yang dapat meningkatkan reaktivitas dari sorbent $\mathrm{Ca}(\mathrm{OH})_{2}$ (Liu dkk., 2002; Ho dan Shih, 1992; Ishizuka dkk., 2000). Gambar 1 menunjukkan model reaksi pozzolanic $\mathrm{Ca}(\mathrm{OH})_{2}$ dengan silika yang mengandung DE.

Beberapa literatur juga menyebutkan bahwa reaktifitas sorbent sangat tergantung pada luas permukaan kontak sorbent (specific surface area) (Klinspor dkk., 1983; 1984). Secara jelas pengaruh luas permukaan kontak terhadap laju reaksi dengan menggunakan $\mathrm{Ca}(\mathrm{OH})_{2}$ sebagai sorbent padat telah dilaporkan oleh beberapa literatur (Irabien dkk., 1992; Ortiz dkk., 1993). Tsuchiai dkk (1995) menyebutkan bahwa penghilangan gas maksimum diperoleh ketika pada waktu sebuah sorbent mencapai diameter pori rata-rata (mean pore diameter) maksimum, tetapi pada saat itu luas permukaan kontak spesifik (specific surface area) belum mencapai maksimum. Renado dkk. (1999) menunjukkan bahwa volume mesopore dan macropore merupakan komponen yang paling utama yang berhubungan dengan reaktifitas sorbent dan konversi penyisihan gas.

Lin dan Shih (2003) menyebutkan bahwa peningkatan luas permukaan kontak spesifik (specific surface area) sangat dipengaruhi oleh peningkatan volume total pori. Jozewicz dkk. (1987) menyebutkan bahwa peningkatan spesies hidrat (hydrated species) yang terdapat di dalam permukaan sorbent dapat meningkatkan reaktifitas padatan dan diharapkan untuk menghilangkan hidrasi air dengan pengontakan sorbent dan gas panas untuk menghasilkan pori baru yang mempunyai luas permukaan kontak baru. Peristiwa ini umumnya dikenal dengan proses kalsinasi.

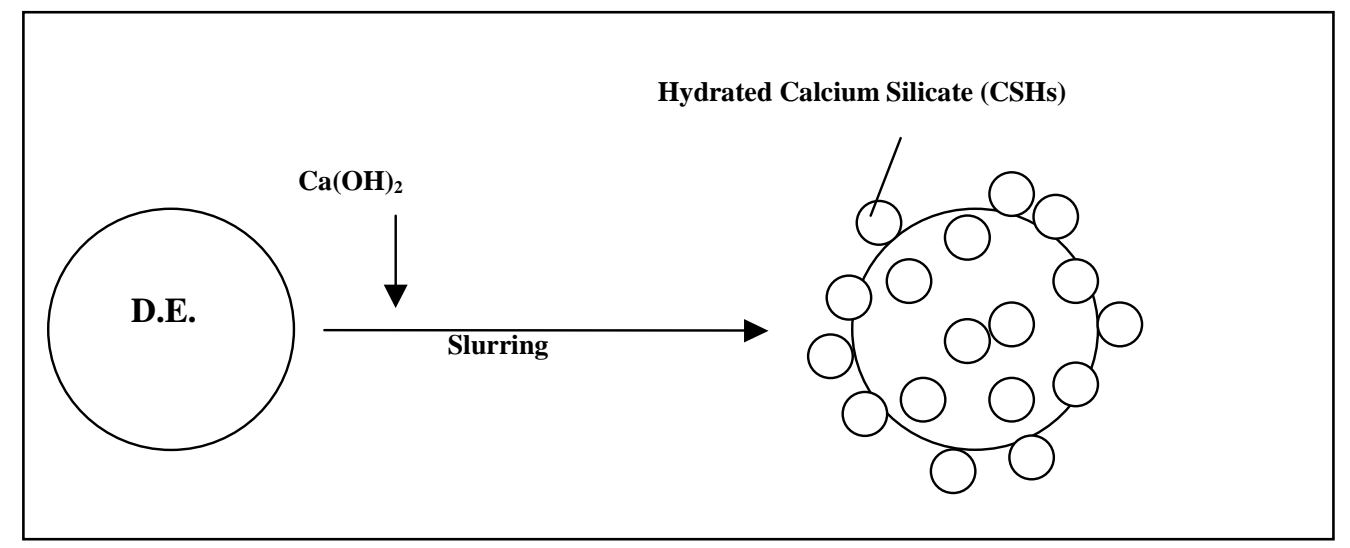

Gambar 1. Model reaksi pozzolanic $\mathrm{Ca}(\mathrm{OH})_{2}$ dengan silika yang terkandung dalam DE (Liu, 2002) 
Jika reaktifitas sorbent sangat tergantung pada luas permukaan kontak spesifik (specific surface area) dan volume total pori, maka sangatlah penting untuk meningkatkan luas permukaan kontak spesifik dan volume pori dari sebuah sorbent padat melalui proses kalsinasi.

Kompos adalah hasil penguraian parsial atau tidak lengkap dari campuran bahan-bahan organik yang dapat dipercepat secara artifisial oleh populasi berbagai macam mikroba dalam kondisi lingkungan yang hangat, lembab, dan aerobik atau anaerobic. Pengomposan adalah proses dimana bahan organik mengalami penguraian secara biologis, khususnya oleh mikroba-mikroba yang memanfaatkan bahan organik sebagai sumber energi. Membuat kompos adalah mengatur dan mengontrol proses alami tersebut agar kompos dapat terbentuk lebih cepat. Proses ini meliputi membuat campuran bahan yang seimbang, pemberian air yang cukup, mengaturan aerasi, dan penambahan aktivator pengomposan.

Kompos sangat bermanfaat untuk mengurangi tingkat cemaran udara yang berasal dari sumbersumber zat pencemar berupa bahan organik mudah menguap yang banyak digunakan sebagai pelarut pada industri kimia, industri polimer dan laboratorium seperti gas CO dan senyawa hidrokarbon lainnya (Supriyono, 1999). Penelitian tentang modifikasi sorbent $\mathrm{Ca}(\mathrm{OH})_{2}$ dengan $\mathrm{DE}$ dan kompos sejauh ini belum diketemukan.

Penelitian ini difokuskan pada persiapan absorbent $\mathrm{Ca}(\mathrm{OH})_{2}$ yang mempunyai reaktifitas yang tinggi dengan penambahan additive tanah diatome (DE) dan kompos.

\section{METODE PENELITIAN}

Bahan yang digunakan adalah berupa: (1) $\mathrm{Ca}(\mathrm{OH})_{2}$; (2) tanah diatome; (3) kompos; dan (4) aquades. Kapur hidrat (hydrated lime) yang digunakan dalam percobaan ini adalah $\mathrm{Ca}(\mathrm{OH})_{2}$ murni $(99.9 \%$ $\left.\mathrm{Ca}(\mathrm{OH})_{2}\right)$, sedangkan tanah diatome (DE) yang digunakan berasal dari NAD dengan komposisi: $\mathrm{SiO}_{2}$ $=33,94 \%, \mathrm{Al}_{2} \mathrm{O}_{3}=4,89 \%$ dan innert $=61,17 \%$ (Data primer, Baristan, 2009). Sedangkan kompos yang digunakan merupakan pupuk kompos olahan limbah sawit dengan komposisi: air $=45-50 \%$, abu $=12,6 \%$, $\mathrm{N}=2-3 \%, \mathrm{C}=35,1 \%, \mathrm{P}=0,2-04 \%, \mathrm{~K}=4-6 \%, \mathrm{Ca}=$ $1-2 \%, \mathrm{Mg}=0,8-1,0 \%, \mathrm{C} / \mathrm{N}=15,03 \%$ dan bahan organik $>50 \%$ (Supriyono, 1999).

Peralatan yang dipersiapkan meliputi: (1) erlemenyer; (2) pipet volum; (3) aluminium foil; (4) corong pemisah; (5) gelas ukur; (6) magnetic stirrer/water batch; dan (6) termometer. Persiapan sorbent $\mathrm{Ca}(\mathrm{OH})_{2} / \mathrm{DE}$ ditunjukkan pada Gambar 2.

Tanah diatome dan kompos dihaluskan dan diayak sesuai dengan variable proses yang dilakukan. Kapur hidrat dan additive DE, bersama-sama dengan $100 \mathrm{~g}$ air dimasukkan ke dalam beaker polypropylene conical pada berbagai variasi rasio $\mathrm{Ca}(\mathrm{OH})_{2} /$ additives dengan rasio berat air/padatan $\left(\mathrm{Ca}(\mathrm{OH})_{2}+\right.$ additives $)$ adalah 10.

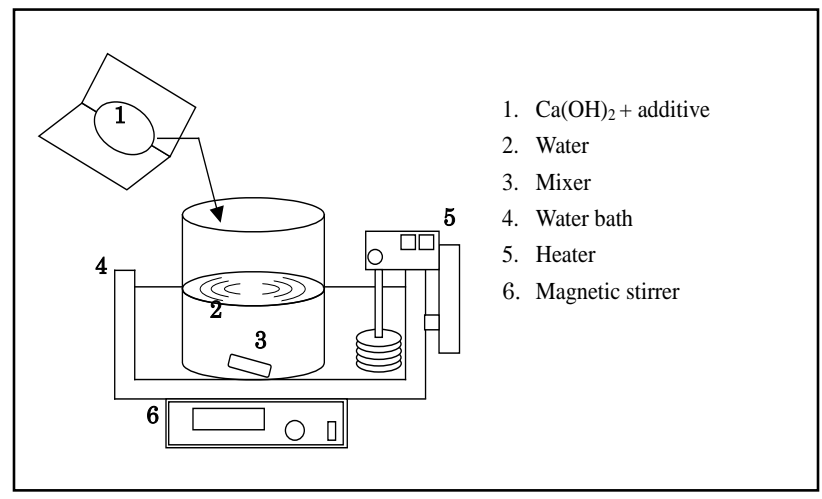

Gambar 2. Skema reaktor batch berpengaduk

Beaker kemudian ditutup dan dimasukkan ke dalam was water bath pada temperatur $65^{\circ} \mathrm{C}$. Kemudian diaduk dengan magnetic stirrer selama 2 jam. Setelah diaduk, slurry dikeringkan selama 24 jam pada temperature $120^{\circ} \mathrm{C}$ dan solid kemudian dikalsinasi pada berbagai variasi temperature selama 2 jam. Cake hasil pengeringan dihaluskan dan kemudian dilakukan analisa spesifik surface area (SBET). Cake sorbent $\mathrm{Ca}(\mathrm{OH})_{2} / \mathrm{DE}$ dengan kehalusan 350 mesh dicampur dengan kompos 350 mesh dengan perbandingan 3:1:1.

Sorbent $\quad \mathrm{Ca}(\mathrm{OH})_{2} / \mathrm{DE} /$ kompos kemudian dimasukkan ke dalam fixed bed reaktor pada keteinggian tertentu $(2 \mathrm{~cm}, 4 \mathrm{~cm}, 6 \mathrm{~cm})$ untuk test aktifitas. SEM, Hitachi S-3000N digunakan untuk melihat marfologi sorbent. Konsentrasi gas masuk dan keluar reaktor dnalisa dengan menggunakan Bacharach.Inc 450 Analyzer. Adapun skema proses penjerapan gas masing-masing ditunjukkan pada Gambar 3.

\section{HASIL DAN PEMBAHASAN \\ Pengaruh Jenis Sorbent Terhadap Efesiensi Penjerapan Gas}

Gambar 4 menunjukkan bahwa efisiensi penjerapan gas $\mathrm{CO}$ untuk semua jenis sorbent berada diatas $10 \%$. Efesiensi penjerapan gas CO yang paling tinggi adalah pada sorbent $\mathrm{Ca}(\mathrm{OH})_{2}+\mathrm{DE}+$ kompos yaitu sebesar $48,761 \%$ dalam variabel percobaan yang dilakukan. Hal ini dikarenakan sorbent memiliki kandungan gugus silika yang berfungsi sebagai peningkat reaktifitas sorbent serta adanya komponen kompos seperti bakteri yang dapat menguraikan gas $\mathrm{CO}$ menjadi gas metana dengan adanya Hidrogen dan gas $\mathrm{CO}_{2}$ dengan adamya oksigen. Menurut Suprapto (2003), kehadiran kompos di dalam sorbent $\mathrm{Ca}(\mathrm{OH})_{2}$ dapat meningkatkan penurunan konsentrasi $\mathrm{CO}$ di dalam gas hasil pembakaran. 


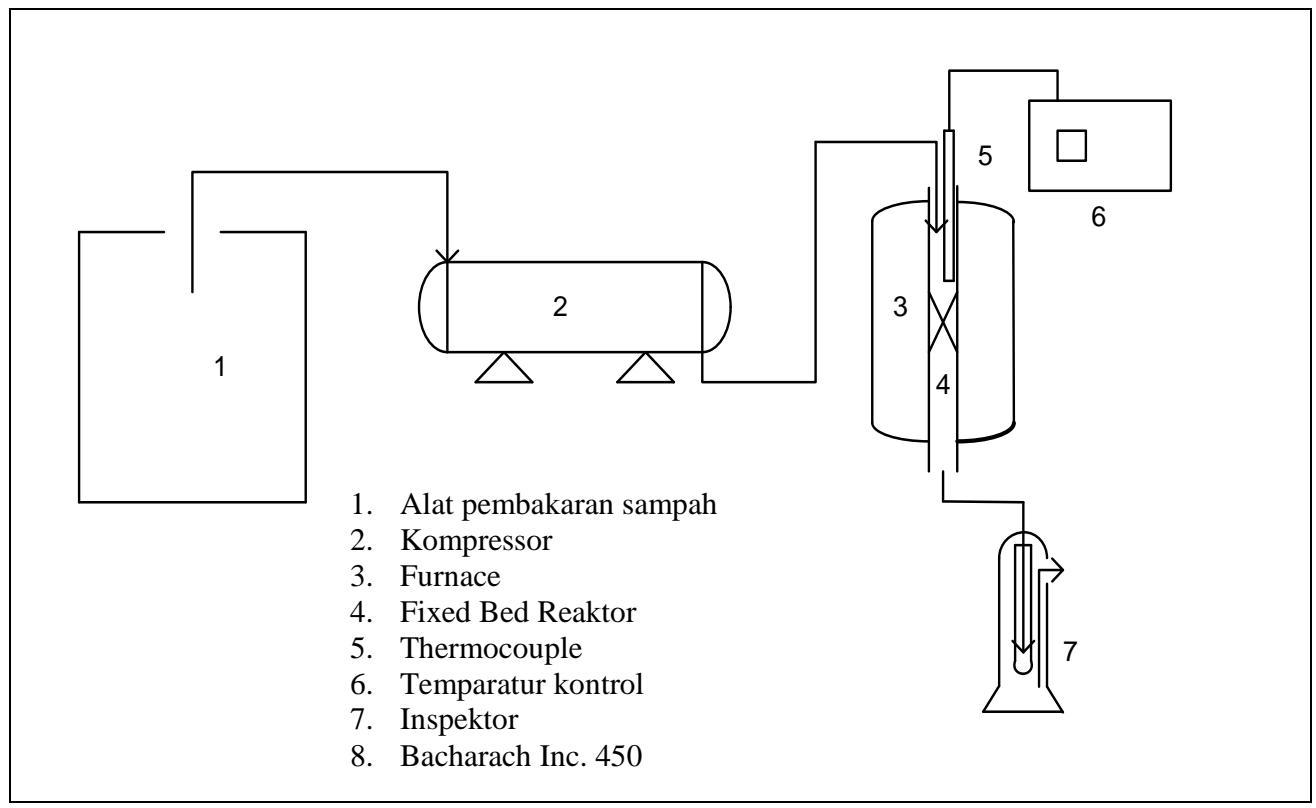

Gambar 3 Skema rangkaian proses penjerapan gas

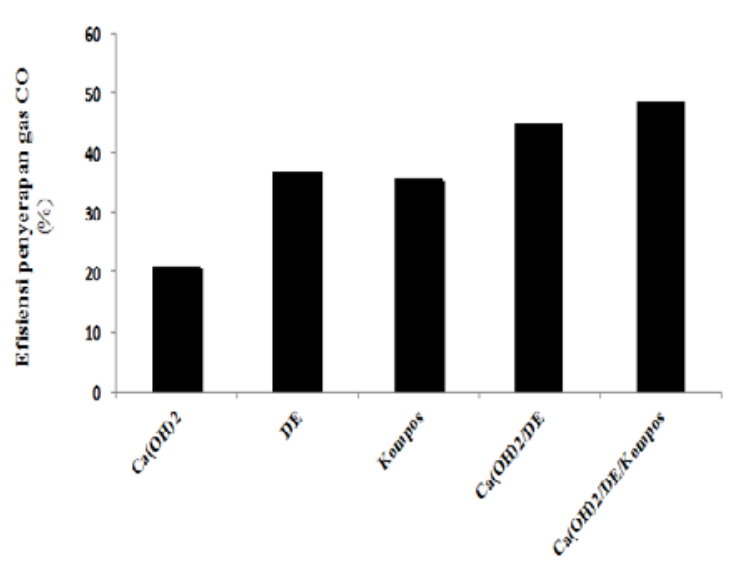

Gambar 4. Pengaruh jenis sorbent terhadap efesiensi penjerapan gas pada $\mathrm{T}=150^{\circ} \mathrm{C}$ dan tinggi unggun $6 \mathrm{~cm}$

Penurunan konsentrasi CO ini dikarenakan terdapat bakteri anaerobic seperti Methanobacterium dan Methanocarcina dapat mengubah gas CO menjadi metana dengan adanya hydrogen. Hidrogen terbentuk dari reaksi antara $\mathrm{Ca}(\mathrm{OH})_{2}$ dengan gas $\mathrm{CO}$ hasil pembakaran (Alizar, 2005).

$$
\mathrm{CO}_{(\mathrm{g})}+\mathrm{Ca}(\mathrm{OH})_{2(\mathrm{~s})} \rightarrow \mathrm{Ca}(\mathrm{CO})_{3(\mathrm{~s})}+\mathrm{H}_{2(\mathrm{~g})}
$$

Karbonmonoksida dioksidasi dan berlaku sebagai donor electron selama pertumbuhan berbagai bakteri Clostridia. Beberapa bakteri aerobik yan lain dalam bentuk populasi campuran dapat mengubah gas CO menjadi metana dengan adanya hidrogen (Suprapto, 2003).

$$
\mathrm{CO}_{(\mathrm{g})}+3 \mathrm{H}_{2(\mathrm{~g})} \rightarrow \mathrm{CH}_{4(\mathrm{~g})}+\mathrm{H}_{2} \mathrm{O}_{(\mathrm{l})}
$$

Beberapa bakteri anaerobik Methano-carcina dan Methanobacterium dengan adanya hidrogen dapat mengubah gas $\mathrm{CO}$ menjadi $\mathrm{CH}_{4}$ dan tanpa menggunakan oksigen dapat mengoksidasi CO menjadi $\mathrm{CO}_{2}$ (Kluyver dan Schellen, 1974).

$$
4 \mathrm{CO}+2 \mathrm{H}_{2} \mathrm{O} \rightarrow 3 \mathrm{CO}_{2}+\mathrm{CH}_{4}
$$

Spesies seperti Carboxydomonas, Hydrogennomonas, Bacillus dan bakteri pengoksidasi tanah dapat mengoksidasi gas $\mathrm{CO}$ menjadi $\mathrm{CO}_{2}$ (Hubley, 1974).

$$
\mathrm{CO}_{(\mathrm{g})}+1 / 2 \mathrm{O}_{2(\mathrm{~g})} \rightarrow \mathrm{CO}_{2(\mathrm{~g})}
$$

Di samping hal tersebut di atas penjerapan gas CO lebih tinggi menggunakan modifikasi sorbent $\mathrm{Ca}(\mathrm{OH})_{2} / \mathrm{DE} /$ kompos dikarenakan porositas sorbent $\mathrm{Ca}(\mathrm{OH})_{2}+\mathrm{DE}$ lebih besar dibandingkan sorbent $\mathrm{Ca}(\mathrm{OH})_{2}$ murni. Hal ini dapat dilihat dari hasil analisa SEM yang ditunjukkan pada Gambar 5.

Gambar 5 menunjukkan bahwa porositas sorbent $\mathrm{Ca}(\mathrm{OH})_{2}+\mathrm{DE}$ lebih besar daripada porositas sorbent $\mathrm{Ca}(\mathrm{OH})_{2}$ murni, sehingga efesiensi penjerapan gas lebih tinggi pada sorbent $\mathrm{Ca}(\mathrm{OH})_{2}+\mathrm{DE}$. Hal ini sesuai dengan penelitian yang dilakukan oleh Mariana (2003) yang menyatakan bahwa sorbent $\mathrm{Ca}(\mathrm{OH})_{2}+\mathrm{DE}$ mempunyai porous yang lebih besar dari sorbent $\mathrm{Ca}(\mathrm{OH})_{2}$ murni seperti ditunjukkan pada Gambar 6 . Reaksi pozzolanic antara silika dengan $\mathrm{Ca}(\mathrm{OH})_{2}$ di dalam larutan (slurry) membentuk kalsium silikat hidrat (hydrated calcium silicates (CSHs)) dan kalsium alumina (CAHs) yang tinggi yang dapat meningkatkan reaktivitas dari sorbent $\mathrm{Ca}(\mathrm{OH})_{2}$ (Liu dkk., 2002), seperti yang ditunjukkan pada reaksi berikut:

$$
\mathrm{Ca}(\mathrm{OH})_{2}+\mathrm{SiO}_{2}+\mathrm{H}_{2} \mathrm{O} \rightarrow \mathrm{CaO} \cdot \mathrm{SiO}_{2} \cdot 2 \mathrm{H}_{2} \mathrm{O}
$$






(a)

(b)

Gambar 5. Profil SEM untuk: (a) $\mathrm{Ca}(\mathrm{OH})_{2}$, (b) $\mathrm{Ca}(\mathrm{OH})_{2}+\mathrm{DE}$

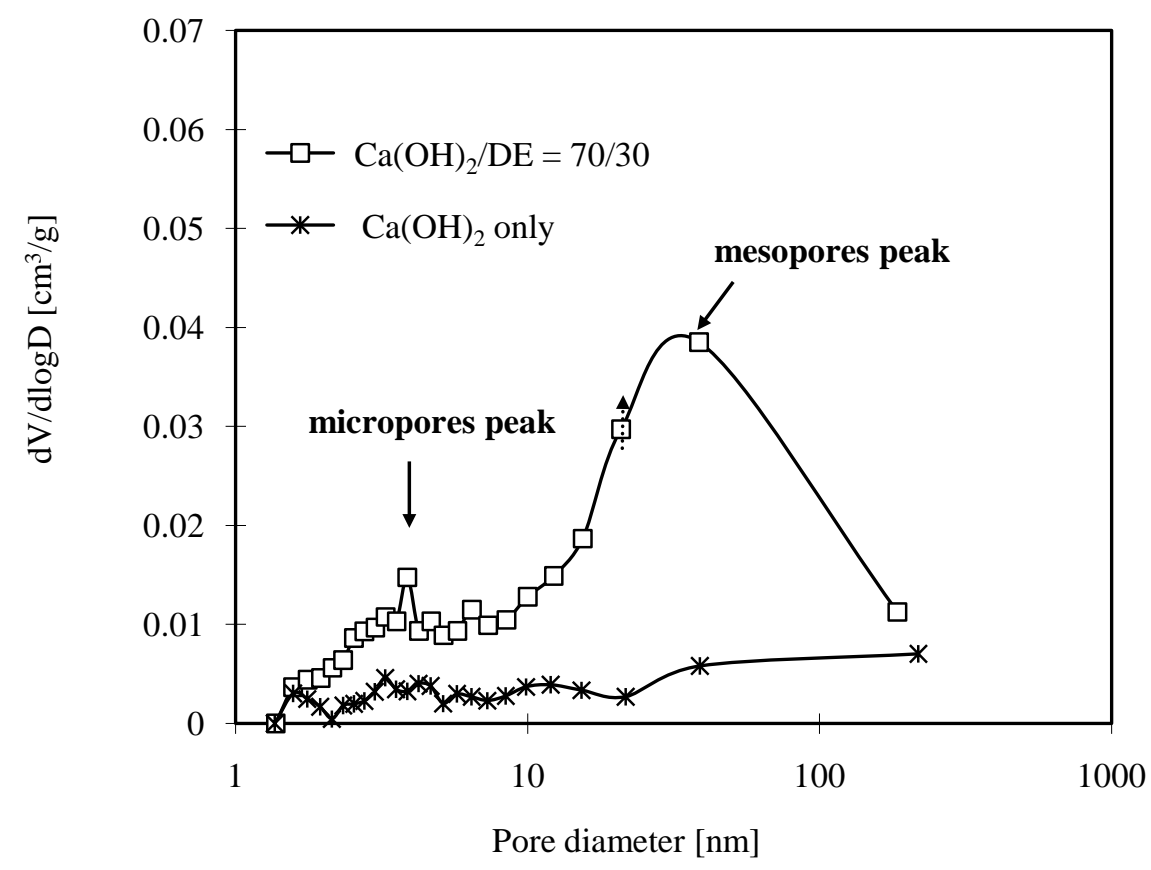

Gambar 6. Pengaruh jenis sorbent terhadap diameter pori (Mariana, 2003)

\section{Pengaruh Tinggi Unggun Terhadap Efesiensi Penjerapan Gas}

Secara umum tinggi unggun berpengaruh terhadap efesiensi penjerapan gas, semakin tinggi unggun maka efesiensi penjerapan gas akan semakin tinggi. Hal ini disebabkan karena kontak antara sorbent dengan gas semakin lama, sehingga gas yang terserap akan semakin besar. Hal ini sesuai dengan penelitian yang dilakukan oleh Suprapto (2003) yang menyatakan bahwa semakin tinggi unggun maka efesiensi penjerapan gas akan semakin besar, pada tinggi unggun $15 \mathrm{~cm}$ gas yang terserap adalah $45 \%$ sedangkan pada tinggi unggun $75 \mathrm{~cm}$ gas yang terserap adalah 91,06\%. Gambar 7 memperlihatkan pengaruh ketinggian unggun terhadap efesiensi penjerapan gas untuk masing-masing sorbent.

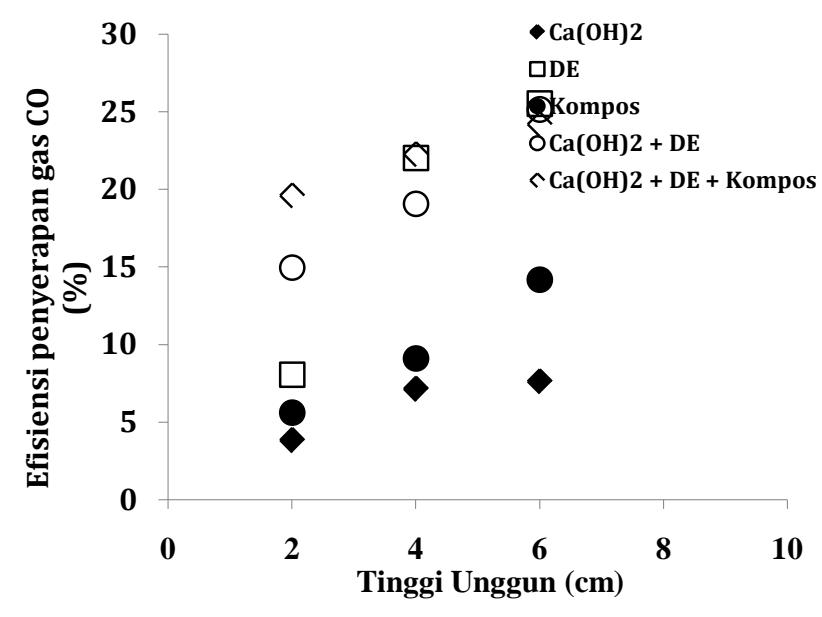

Gambar 7. Hubungan antara tinggi unggun terhadap efesiensi penjerapan gas pada $\mathrm{T}=50^{\circ} \mathrm{C}$ 
Unggun merupakan salah satu faktor yang mempengaruhi penyisihan gas $\mathrm{CO}$ hasil pembakaran dengan menggunakan proses absorpsi. Unggun yang tinggi akan memperlama gas hasil pembakaran melewati sorbent sehingga akan memperbanyak kontak antara gas dan sorbent. Ketinggian unggun juga akan mempengaruhi pressure drop yang dihasilkan dimana dengan laju alir dan waktu reaksi yang sama. Setiap jenis sorbent akan terjadi perbedaan tekanan pada unggun bagian atas dan unggun bagian bawah. Gambar 7 juga menunjukkan bahwa sorbent $\mathrm{Ca}(\mathrm{OH})_{2}+\mathrm{DE}+\mathrm{Kompos}$ dan sorbent DE dapat menyisihkan gas CO terbanyak pada saat tinggi unggun maksimum $6 \mathrm{~cm}$ dibandingkan pada saat tinggi unggun 2 dan $4 \mathrm{~cm}$. Pada sorbent lainya terjadi penurunan gas $\mathrm{CO}$ yang terserap disaat unggun maksimum. Hal ini dapat terjadi oleh beberapa faktor antara lain faktor tekanan dan porositas sorbent.

\section{Pengaruh temperatur terhadap konsentrasi gas yang terserap}

Gambar 8 menunjukkan bahwa semakin tinggi temperatur maka efesiensi penjerapan gas semakin meningkat dalam range variabel penelitian yang dilakukan. Hal ini sesuai dengan penelitian yang dilakukan oleh Jozewicz (1987) yang menyatakan bahwa semakin tinggi temperatur maka luas permukaan sorbent akan semakin luas, sehingga gas yang terserap semakin banyak. Jozewicz (1987) juga menyebutkan bahwa peningkatan hydrated species yang terdapat di dalam permukaan sorbent dapat meningkatkan reaktifitas padatan dan diharapkan untuk menghilangkan hidrasi air dengan pengontakan sorbent dan gas panas untuk menghasilkan pori baru yang mempunyai luas permukaan kontak baru. Efesiensi penjerapan gas CO yang paling bagus adalah 48,761\% menggunakan sorbent $\mathrm{Ca}(\mathrm{OH})_{2}+\mathrm{DE}+\mathrm{kompos}$ pada temperatur $150^{\circ} \mathrm{C}$.

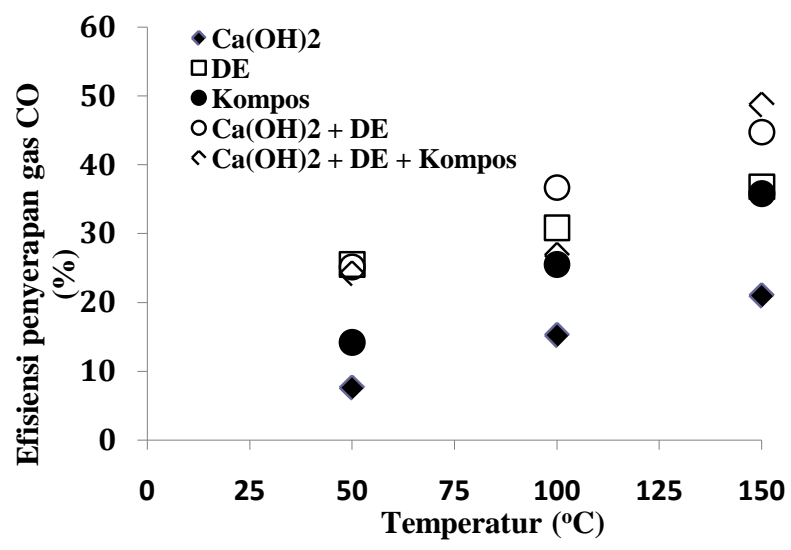

Gambar 8. Hubungan antara temperatur reaksi terhadap efesiensi penjerapan gas

Gambar 8 juga menunjukkan bahwa semakin tinggi temperatur, maka peningkatan efisiensi penjerapan gas $\mathrm{CO}$ dengan sorben $\mathrm{Ca}(\mathrm{OH})_{2}+\mathrm{DE}+$ kompos semakin signifikan dibandingkan keempat sorben lainnya. Hal ini disebabkan karena porositas sorben semakin meningkat dengan meningkatnya temperatur karena terjadinya proses penghilangan hidrasi air dengan pengontakan sorbent menghasilkan pori baru yang mempunyai luas permukaan kontak baru (Jozewicz dkk. (1987). Hal ini juga sesuai dengan hasil penelitian yang dilaporkan oleh Jayshri (2012).

\section{KESIMPULAN}

Dari hasil pembahasan penelitian ini dapat disimpulkan bahwa semakin tinggi unggun dan temperatur, maka efesiensi penjerapan gas semakin tinggi. Sorbent yang paling baik untuk menyerap gas $\mathrm{CO}$ adalah sorbent $\mathrm{Ca}(\mathrm{OH})_{2} / \mathrm{DE} / \mathrm{kompos}$ sebesar 48,761\%, pada tinggi unggun $6 \mathrm{~cm}$ dan temperatur $150^{\circ} \mathrm{C}$. Kompos dapat dijadikan sebagai sorbent karena memiliki kemampuan untuk mendegradasikan gugus CO menjadi gugus Metana oleh adanya bakteri anaerob.

\section{UCAPAN TERIMA KASIH}

Penulis mengucapkan terimakasih kepada Direktorat Jenderal Pendidikan Tinggi, Departemen Pendidikan Nasional yang telah membiayai penelitian ini sesuai dengan Surat Perjanjian Pelaksanaan Hibah Kompetitif Penelitian Sesuai Prioritas Nasional Nomor: 399/SP2H/PL/Dit.Litabmas/IV/2011, tanggal 14 April 2011. Ucapan terimakasih juga kepada member Lab Operasi Teknik Kimia, Unsyiah dan mahasiswa yang telah membantu dalam pelaksanaan penelitian ini.

\section{DAFTAR PUSTAKA}

Alizar (2005), Teknologi Bahan Konstruksi, Pusat Pengembangan Bahan Ajar, UMB.

Castilho, S., Kiennemann, A., Francisco, M.C.P and Dias, A.P.S (2013), Sorbents for $\mathrm{CO}_{2}$ capture from biogenesis calcium wastes, Chemical Engineering Journal, 226, pp. 146-153.

Fujioka, S., Kaneko, K., Terasaka, K., Sasada, Y., Goshima, T. and Kobayashi, D. (2012), Development of Multislit-Bubble Distributor for Gas Adsorption, $J$. Chem. Eng. Japan, 45, 9, pp. 691-695.

Garea, A., Viguri, J.R. and Irabien, A. (1996), Kinetics of Flue Gas Desulfurization at Low Temperatures: Fly ash/Ca(OH) $)_{2} \quad(3 / 1)$ Sorbent Behavier,”Chem. Eng. Sci., 52, 5, pp. 715-732.

Ho, C.S, and Shih, S.M. (1992), $\mathrm{Ca}(\mathrm{OH})_{2} /$ Fly Ash Sorbents for $\mathrm{SO}_{2}$ Removal, Ind. Eng. Chem. Res., 31, pp. 1130-1135.

Iizuka, A., Yamasaki, A. and Yanagisawa, Y. (2013), Cost Evaluation for a Carbon Dioxide Sequestration Process by Aqueous Mineral Carbonation of Waste Concrete, J. Chem. Eng. Japan, 46, 4, pp. 326-334. 
Irabien, Cortabitart, A.F. and I. Ortiz (1992), Kinetics of Flue Gas Desulfurization at Low Temperatutes, Nonideal Surface Adsorption Model, Chem. Eng. Sci. 47, pp. 1533-1543.

Ishizuka, T., Tsuchiai, H., Murayama, T., Tanaka, T. and Hattori, H. (2000), Preparation of Active Absorbent for Dry-Type Flue Gas Desulfurization from Calcium Oxide, Coal Fly Ash, and Gypsum, Ind. Eng. Chem. Res., 39, pp. 1390-1396.

Jayshri A. T., Ravikrishna, V.T., Kartik, S.I., Vivek, K., Arti, N.V., Nitin, K.L., Rajesh, B.N., Yenkie, M.K.N and Sadhana, S.R. (2012), N-doped mesoporous alumina for adsorption of carbon dioxide, Journal of Environmental Sciences, 24, 11, pp. 1972 1978.

Jozewicz, Chang, W., Brna, J., Sedman, T. (1987), Reactivation of Solids from Furnace Injection of Limestone for $\mathrm{SO}_{2}$ Control, Environ. Sci. Technol. 21, 7, pp. 664-670.

Kanai, Y., Terasaka, K., Suwabe, M., Fujioka, S. and Kobayashi, D. (2012), Development of Slurry Bubble Column with Lithium Silicate to Recover Hot Hot $\mathrm{CO}_{2}$ Gas from Flue Gas, J. Chem. Eng. Japan, 45, 9, pp. 639-644.

Klingspor, J., Karlsson, H.T. and Bjerle, I. (1983), A Kinetic Study of the Dry $\mathrm{SO}_{2}$-Limestone Reaction at Low Temperature, Chem. Eng. Com., 22, pp. 81.

Klingspor, J., A. Stromberg, H.T. Karlsson and I. Bjerle (1974), "Similarities Between Lime and Limestone in Wet-dry Scrubbing," Chem. Eng. Proc., 18, 239, 1984

Kluyer, A.J. and Schullen, C.G.T.P. (1974), Arch Biochemical.
Lin, R.B and Shih, S.M. (2003), Characterization of $\mathrm{Ca}(\mathrm{OH})_{2} /$ fly ash sorbent for flue gas desuldurization, Power Tech, 131, pp. 212-222.

Liu, C.F, Shih, S.M. and Lin, R.B. (2002), Kinetic of the Reaction of $\mathrm{Ca}(\mathrm{OH})_{2}$ /Fly Ash Sorbent with $\mathrm{SO}_{2}$ at Low Temperatures, Chem. Eng. Sci., 57, pp. 93-104.

Mariana, Chen, C., Tsujimura, Y., Maezawa, A. and Uchida, S. (2003), Experiments on $\mathrm{SO}_{2}$ Absorption in a Bag Filter Based on the Grain Model, J. Chin. Inst. Chem. Engrs., 34, 2, pp. 2009-2011.

Renedo, M.J., Fernandez, J., Garea, A., Ayerbe, A. and Irabien, J.A. (1999), Microstructural Changes in the Desulfurization Reaction at Low Temperature, Ind. Eng. Chem. Res. 38, pp. 1384-1390.

Seno, T., Maezawa, A., Fujiwara, T. and Uchida, S. (1996), Simultaneous Absorption of Acid Gases by Slaked Lime in Bag Filter System, Proc. of $4^{\text {th }}$ Joint Int. Conf. On Separation Technology (ISST02-JK), Tokyo, Japan, pp. 263-266.

Suprapto, J (2003), Pengolahan Gas Karbon Monoksida dalam Gas Buang dengan Biofilter Universitas Diponegoro, Semarang.

Supriyono (1999), Pencemaran udara bisa merusak ruku dan gangguan kesehatan staf perpustakaan, Media pustakawan, 4, hal. 3-9.

Tsuchiai, H, Ishizuka, T., Ueno, T., Hattori, H. and Kita, $\mathrm{H}$ (1995), Highly Active Sorbent for $\mathrm{SO}_{2}$ Removal prepared from Coal Fly Ash, Ind. Eng. Chem. Res. 34, pp.1404-1411.

Uchida, S., Kageyama, S., Nogi, M. and Karakida, H. (1979), Reaction Kinetics of $\mathrm{HCl}$ and Limestone, $J$. Chin. Inst. Chem. Eng., 10, pp. 45-49 